\title{
PENDIDIKAN INKLUSI SEBAGAI ALTERNATIF SOLUSI MENGATASI PERMASALAHAN SOSIAL ANAK PENYANDANG DISABILITAS
}

\author{
Auhad Jauhari \\ Mahasiswa Pasca Sarjana UIN Walisongo Semarang, \\ Jawa Tengah Indonesia \\ jauhari@gmail.com
}

\begin{abstract}
Children with disabilities have the same rights as children in general to get an education. Unfortunately, the availability of adequate education for children with special needs is inadequate and equitable. As the provision of extraordinary schools only exist in big cities. Inclusion education comes as an alternative solution to solve the social problems of children with disabilities. The purpose of establishing inclusive schools is to minimize the impacts caused by exclusive attitudes. Inclusion schools also provide opportunities for children with special needs and less able to graduate education.
\end{abstract}

Keywords: inclusive education, social issues, children with disabilities

Anak-anak penyandang cacat memiliki hak yang sama dengan anakanak pada umumnya untuk mendapatkan pendidikan. Sayangnya, ketersediaan pendidikan yang memadai untuk anak berkebutuhan khusus tidak memadai dan setara. Karena penyediaan sekolah luar biasa hanya ada di kota-kota besar. Pendidikan inklusi datang sebagai solusi alternatif untuk mengatasi masalah sosial anak penyandang cacat. Tujuan pembentukan sekolah inklusif adalah meminimalkan dampak yang ditimbulkan oleh sikap eksklusif. Sekolah inklusi juga memberi kesempatan kepada anak berkebutuhan khusus dan kurang mampu menempuh pendidikan pascasarjana.

Kata kunci: pendidikan inklusi, masalah sosial, anak cacat 


\section{PENDIDIKAN INKLUSI SEBAGAI ALTERNATIF SOLUSI...}

\section{A. PENDAHULUAN}

Permasalahan anak penyandang Disabilitas akan terus meningkat seiring meningkatnya tekanan dari lingkungan sosial .Anak penyandang Disabilitasakan terus mengalami keterbatasan karena ada yang salah dengan cara pandang masyarakat terhadap penyandang Disabilitas (Oliver, 1996).Pendapat ini menunjukkan bahwa yang menimbulkan masalah sosial terhadap anak penyandang Disabilitas adalah masyarakat itu sendiri yang menekan dan memberikan keterbatasan terhadap anak penyandang Disabilitas.

Selama ini pandangan masyarakat terhadap penyandang Disabilitas sebagai kaum yang memiliki ketidakmampuan dan keterbatasan fisik ataupun mental, yang selalu menjadi beban, tidak berguna, harus selalu dibantu dan dikasihani.Pandangan masyarakat yang negatif terhadap penyandang Disabilitas disebabkan karena budaya yang masih melekat di masyarakat. Misalnya banyak keluarga yang beranggapan bahwa memiliki anak Disabilitas merupakan sebuah aib sehingga anak mereka hanya dipingit di dalam rumah tidak bersosialisasi dengan lingkungan sekitar, tidak mengenyam pendidikan yang tentunya berdampak pada psikis si anak dan masa depannya.

Pendidikan sangat dibutuhkan bagi anak-anak untuk mencapai kesejahteraan sosialnya. Tak terkecuali anak-anak yang kurang beruntung baik dalam segi fisik maupun mental. Namun kenyataan di lapangan, anak-anak yang kurang beruntung dan berkebutuhan khusus menjadi anak yang dapat dikatakan mendapat pengecualian.

Rencana pendidikan nasional, pendidikan untuk belum semua terpenuhi. Sebanyak 49.647 anak berkebutuhan khusus dari total sekitar satu juta anak berkebutuhan khusus yang dapat mengenyam pendidikan.Eksklusivitas dalam pendidikan menutup kesempatan bagi anak berkebutuhan khusus dalam memperoleh pendidikan. Sikap eksklusivitas semakin membuat anak yang kurang beruntung dan berkebutuhan khusus semakin terpinggirkan.

Salah satu cara untuk mengatasi permasalahan sosial anak penyandang Disabilitas adalah dengan pendidikan inklusi. Pendidikan inklusi merupakan model pendidikan yang memberi kesempatan bagi siswa yang berkebutuhan khusus untuk belajar 
bersama siswa-siswa lain seusianya yang tidak berkebutuhan khusus.Pendidikan inklusi lahir atas dasar prinsip bahwa layanan sekolah seharusnya diperuntukkan untuk semua siswa tanpa menghiraukan perbedaan yang ada, baik siswa dengan kondisi kebutuhan khusus, perbedaan sosial, emosional, cultural, maupun bahasa (Leni, 2008: 202).Tujuan dari dibentuknya sekolah inklusi adalah untuk menekan dampak yang ditimbulkan oleh sikap eksklusif. Sekolah inklusi juga memberikan kesempatan bagi anak berkebutuhan khusus dan kurang berutung dapat mengenyam pendidikan.

\section{B. PEMBAHASAN}

\section{Pengertian Anak Penyandang Disabilitas}

Pengertian anak penyandang Disabilitas menurut Konvensi Mengenai Hak-hak Penyandang Disabilitas yang telah disahkan dengan UU No 19 Tahun 2011 tentang Pengesahan Konvensi Mengenai Hak-hak Penyandang Disabilitas, penyandang Disabilitas termasuk mereka yang memiliki keterbatasan fisik, mental, intelektual, atau sensorik dalam jangka waktu lama di mana ketika berhadapan dengan berbagai hambatan, hal ini dapat menghalangi partisipasi penuh dan efektif mereka dalam masyarakat berdasarkan kesetaraan dengan yang lainnya (Convention on the Rights of the Child, 1989: 20). Konvensi ini tidak memberikan batasan tentang penyandang cacat.Dalam konvensi ini penyandang cacat disebut sebagai penyandang Disabilitas.Namun karena kecacatan yang disandangnya penyandang cacat/Disabilitas mengalami hambatan fisik, mental dan sosial, untuk mengembangkan dirinya secara maksimal.

Munculnya istilah penyandang Disabilitas di Indonesia setelah adanya diskusi oleh Komnas HAM (Komisi Nasional Hak Asasi Manusia) yang bertajuk, “ Diskusi Pakar Untuk Memilih Terminologi Pengganti Istilah Penyandang Cacat" pada 19-20 Maret 2010 di Jakarta. Diskusi dihadiri oleh pakar HAM, pakar bahasa, pakar komunikasi, pakar filsafat, pakar psikologi, pakar penyandang cacat, pakar isu rentan, perwakilan kementrian sosial, komisioner Komnas HAM.Hasil diskusi terfokus berhasil menemukan dan menyepakati terminologi penyandang Disabilitas sebagai pengganti istilah 


\section{PENDIDIKAN INKLUSI SEBAGAI ALTERNATIF SOLUSI...}

penyandang cacat (http://daksa.or.id/istilah-penyandangDisabilitas-sebagai-pengganti-penyandang-

cacat/\#sthash.vhaZpgul.dpuf, tth).

Peraturan perundang-undangan di Indonesia merumuskan pengertian penyandang Disabilitas dalam pasal 1 angka 1 Undangundang Nomor 4 Tahun 1997 tentang Penyandang Cacat, yang menyatakan bahwa, " Penyandang cacat adalahsetiap orang yang mempunyai kelainan fisik dan/atau mental, yang dapat mengganggu atau merupakan tintangan dan hambatan baginya untuk melakukan secara selayaknya, yang terdiri dari :

a. Penyandang cacat fisik

b. Penyandang cacat mental

c. Penyandang cacat fisik dan mental

\section{Permasalahan Anak Penyandang Disabilitas}

Disabilitas menimbulkan dampak terhadap fisik, pendidikan, vokasional maupun ekonomi. Selain itu akibat dari Disabilitas adalah timbulnya masalah psikososial misalnya anak penyandang Disabilitas akan memiliki kecenderungan untuk rendah diri atau sebaliknya menghargai terlalu berlebihan, mudah tersinggung, terkadang agresif, pesimis, sulit mengambil keputusan, menarik diri dari lingkungan, kecemasan berlebihan, ketidakmampuan dalam hubungan dengan orang lain dan ketidakmampuan mengambil peranan sosial.

Soewito (1993) mengatakan permasalahan anak penyandang Disabilitas dapat dilihat dari empat aspek, yaitu :

a. Aspek yang berasal dari penyandang Disabilitas itu sendiri meliputi (a) hambatan fisik mobilitas, (b) hambatan mental psikologis, (c) hambatan pendidikan,(d) hambatan produktifitas, (e) hambatan sosial ekonomi (f) hambatan fungsi sosial.

b. Aspek dari pihak keluarga meliputi, (a) sikap member perlindungan yang berlebihan yang menghambat perkembangan kemampuan optima, (b) pengetahuan yang rendah, (c) diskriminasi kaarena kurang kesadaran tentang pendidikan bagi anaknya, (d) hal lain seperti malu menampilkan anaknya atau merasa berdosa sehingga terlalu memanjakan. 
c. Aspek dari masyarakat, meliputi (a) masyarakat ragu terhadap kemampuan atau potensi para penyandang Disabilitas, (b) bersifat masa bodoh, (c) lemahnya pengelolaan organisasi bidang kecacatan, (d) terbatasnya lapangan pekerjaan penyandang Disabilitas.

d. Aspek dari pemerintah dimana undang-undang penyandang Disabilitas belum dijalankan dengan baik (Palijama, tth: 54).

Menurut Departemen Sosial, anak penyandang Disabilitas merupakan salah satu kelompok sosial yang di kelompokkan sebagai kelompok yang rawan terhadap masalah - masalah sosial. Hal ini menyebabkankendala tercapainya kesejahteraan sosial bagi anak penyandang Disabilitas. Departemen sosial mengidentifikasikan beberapa hambatan penyandang cacat dalam mencapai kesejahteraan sosial :

a. Memiliki hambatan fisik mobilitas dalam kegiatan sehari - hari

b. Mengalami hambatan / gangguan mental psikologis yang menyebanak penyandang Disabilitasan rasa rendah diri, mengasingkan diri dan tidak percaya diri.

c. Mengalami hambatan komunikasi dalam kegiatan sehari - hari

d. Memiliki hambatan dalam melaksanakan fungsi sosialnya

e. Mengalami hambatan / gangguan dalam ketrampilan kerja produktif.

f. Rawan kondisi sosial ekonomi (Depsos, 2009).

Selain itu masih terdapat sikap dari masyarakat yang kurang menguntungkan seperti :

a. Masih adanya sikap ragu-ragu terhadap kemampuan atau potensi anak penyandang Disabilitas.

b. Masih adanya sikap masa bodoh masyarakat terhadap permasalahan anak penyandang Disabilitas

c. Belum banyak partisipasi masyarakat di dalam menangani permasalahan anak penyandang Disabilitas.

d. Masih lemahnya organisasi sosial yang bergerak di bidang Disabilitas dalam melaksanakan kegiatanya.

e. Masih terbatasnya fasilitas umum yang dapat dipergunakan oleh anak penyandang Disabilitas.

Mencermati permasalahan yang muncul terhadap penyandang Disabilitas diperlukan penanganan atas permasalahan 
yang timbul sebagai akibat dari Disabilitas yang dialami anak penyandang Disabilitas agar dapat menjalankan peran dan fungsi sosialnya sesuai dengan derajat dan jenis Disabilitas yang dialaminya untuk dapat hidup lebih baik.

Dalam UU Nomor 4 Tahun 1997 tentang penyandang cacat disebutkan bahwa "setiap penyandang cacat mempunyai hak yang sama dalam segala aspek kehidupan dan penghidupan". Tentunya aspek-aspek tersebut mencakup pula aspek pendidikan yang menjadi kebutuhan semua orang.Terkait dengan peluang untuk memperoleh pendidikan, UU Nomor 20 Tahun 2003 tentang Pendidikan Nasional dalam pasal 5 ayat 1 disebutkan bahwa setiap warga negara mempunyai hak yang sama untuk memperoleh pendidikan yang bermutu. Pada pasal 5 ayat 2 warga Negara yang mempenyai kelainan fisik, emosional, mental, intelektual dan atau sosial berhak memperoleh pendidikan khusus.

Penjelasan tentang pendidikan khusus ini disebutkan pada pasal 32 ayat 1 , pendidikan merupakan pendidikan bagi peserta didik yang memiliki tingkat kesulitan dalam mengikuti proses pembelajaran karena kelainan fisik, emosional, mental, sosial, dan atau memiliki potensi kecerdasan. Meskipun demikian pada pasal 51 dijelaskan bahwa anak penyandang cacat fisik dan atau mental diberikan kesempatan bersama dalam aksebilitas dalam memperoleh pendidikan biasa.Pasal ini memberi peluang pada anak yang penyandang cacat fisik (anak kebutuhan khusus) untuk memilih mengikuti pendidikan khusus sebagaimana disebutkan pada pasal 5 ayat 2 atau mengikuti pendidikan sebagaimana anak-anak yang biasa (tidak cacat).

Jika ditelusuri sebenarnya persoalan yang sering dijumpai, kendala akses pendidikan bagi anak penyandang Disabilitas ini bukan karena faktor kecacatannya yang disandang, tetapi lebih pada faktor diluar penyandang cacat itu sendiri.Meskipun secara yuridis telah ada peraturan yang mengatur dan memberikan peluang akses pendidikan bagi anak berkebutuhan khusus ini, tetapi peluang itu belum sepenuhnya dapat dinikmati oleh penyandang Disabilitas.Untuk mengatasi permasalahan sosial anak Penyandang Disabilitas salah satunya dengan pendidikan inklusi. 


\section{Auhad Jauhari}

\section{Pengertian Pendidikan Inklusif}

Pendidikan inklusif merupakan suaatu pendekatan pendidikan yang inovatif dan strategis untuk memperluas akses pendidikan bagi semua anak berkebutuhan khusus termasuk anak penyandang Disabilitas.Pendidikan inklusi adalah bentuk penyelenggaraan pendidikan yang menyatukan anak-anak berkebutuhan khusus dengan anak-anak normal pada umumnya untuk belajar.Menurut Hildegun Olsen dalam Tarmansyah, pendidikan inklusi adalah sekolah harus mengakomodasi semua anak tanpa memandang kondisi fisik, intelektual, sosial emosional, linguistik atau kondisi lainnya.Ini harus mencakup anak-anak penyandang cacat, berbakat.Anak-anak jalanan dan pekerja anak berasal dari populasi terpencil atau berpindah-pindah.Anak yang berasal dari populasi etnis minoritas, linguistik, atau budaya dan anak-anak dari area atau kelompok yang kurang beruntung atau termajinalisasi (Tarmansyah, 2007: 82).

Selanjutnya, pengertian pendidikan inklusi menurut Staub dan Peckadalah penempatan anak berkelainan tingkat ringan, sedang, dan berat secara penuh di kelas reguler. Hal ini menunjukkan bahwa kelas reguler merupakan tempat belajar yang relevan bagi anak berkelainan, apapun jenis kelainannya dan bagaimanapun gradasinya(Tarmansyah, 2007: 82).

Sementara itu, Sapon-Shevin menyatakan bahwa pendidikan inklusi sebagai sistem layanan pendidikan yang mempersyaratkan agar semua anak berkelainan dilayani di sekolah-sekolah terdekat, di kelas reguler bersama-sama teman seusianya. Oleh karena itu, ditekankan adanya perombakan sekolah, sehingga menjadi komunitas yang mendukung pemenuhan kebutuhan khusus setiap anak, sehingga sumber belajar menjadi memadai dan mendapat dukungan dari semua pihak, yaitu para siswa, guru, orang tua, dan masyarakat sekitarnya (Direktorat Pendidikan Luar Biasa, 2004: 810).

Alimin menjelaskan bahwa pendidikan inklusi adalah sebuah proses dalam merespon kebutuhan yang beragam dari semua anak melalui peningkatan partisipasi dalam belajar, budaya dan masyarakat, dan mengurangi eklusivitas di dalam pendidikan. Pendidikan inklusif mencakup perubahan dan modifikasi dalam isi, 


\section{PENDIDIKAN INKLUSI SEBAGAI ALTERNATIF SOLUSI...}

pendekatan-pendekatan, struktur dan strategi yang dapat mengakomodasi kebutuhan semua anak seseuai dengan kelompok usianya.Pendidikan inklusif juga dapat dipandang sebagai bentuk kepedulian dalam merespon spekturm kebutuhan belajar peserta didik yang lebih luas, dengan maksud agar baik guru maupun siswa, keduanya memungkinkan merasa nyaman dalam keberagaman dan melihat keragaman sebagai tantangan dan pengayaan dalam lingkungan belajar, keberagaman bukan sebagai masalah. Pendidikan inklusif juga akan terus berubah secara pelan-pelan sebagai refleksi dari apa yang terjadi dalam prakteknya, dalam kenyataan, dan bahkan harus terus berubah jika pendidikaninklusif ingin tetap memiliki respon yang bernilai nyata dalam mengahapi tantangan pendidikan dan hak azasi manusia (Alimin, 2005).

Sedangkan pengertian pendidikan inklusi menurut Permendiknas Nomor 70 Tahun 2009. Pendidikan inklusif adalah system penyelenggaraan pendidikan yang memberikan kesempatan kepada semua peserta didik yang memiliki kelainan dan memiliki potensi kecerdaan dan/atau bakat istimewa untuk mengikuti pendidikan atau pembelajaran dalam satu lingkungan pendidikan secara umum bersama-sama dengan peserta didik umumnya (Peraturan Menteri Pendidikan Nasional, 2009)

Atas dasar pengertian dan dasar pendidikan inklusi tersebut, maka dapat dikatakan bahwa pendidikan inklusi adalah sistem layanan pendidikan yang mensyaratkan anak berkebutuhan khusus belajar di sekolah-sekolah terdekat di kelas biasa bersama temanteman seusianya.Konsep pendidikan inklusi merupakan konsep pendidikan yang mempresentasikan keseluruhan aspek yang berkaitan dengan keterbukaan dalam menerima anak berkebutuhan khusus untuk memperoleh hak dasar mereka sebagai warga negara.

Keberadaan pendidikan inklusi bukan saja penting untuk menampung anak yang berkebutuhan khusus dalam sebuah sekolah yang terpadu, melainkan pula dimaksudkan untuk mengembangkan potensi dan menyelamatkan masa depan mereka dari diskriminasi pendidikan yang cenderung mengabaikan anak-anak berkelainan (Takdir, 2013: 26-27)

Dalam konteks yang lebih luas, pendidikan inklusi juga dapat dimaknai sebagai satu bentuk reformasi pendidikan yang 
menekankan sikap anti diskriminasi, perjuangan persamaan hak dan kesempatan, keadilan, dan perluasan akses pendidikan bagi semua, peningkatan mutu pendidikan, upaya strategis dalam menuntaskan wajib belajar 9 tahun, serta upaya mengubah sikap masyarakat terhadap anak berkebutuhan khusus(Takdir, 2013: 25).

Pendidikan inklusi terjadi manakala pengintegrasian dalam penempatan peserta didik di kelas-kelas reguler berdasarkan atas ide pandangan hidup yang berbeda dengan pandangan sebelumnya.Konsep inklusi berdasarkan atas gagasan bahwa sekolah reguler harus menyediakan lingkungan belajar bagi seluruh peserta didik sesuai dengan kebutuhannya, apapun tingkat kemampuan ataupun kelainannya.Sekolah inklusi menyelenggarakan berbagai keterampilan berkaitan dengan budaya, sosial, kelompok etnik, dan latar belakang sosial (Delphie, 2009: 15).

Menurut Mohammad Takdir Ilahi, tujuan pendidikan inklusi ada dua macam, yakni:

a. Memberikan kesempatan yang seluas-luasnya kepada semua peserta didik yang memiliki kelainan fisik, emosional, mental, dan sosial atau memilki potensi kecerdasan dan bakat istimewa untuk memperoleh pendidikan yang bermutu sesuai dengan kebutuhan dan kemampuannya.

b. Mewujudkan penyelenggaraan pndidikan yang menghargai keanekaragaman, dan tidak diskriminatif bagi semua peserta didik(Takdir, 2013: 39-40).

\section{Karakteristik Pendidikan Inklusi}

Ada beberapa karakteristik pendidikan inklusi yang dapat dijadikan dasar layanan pendidikan bagi anak luar biasa. Karakteristik tersebut antara lain:

a. Kurikulum yang Fleksibel

Penyesuaian kurikulum dalam penerapan pendidikan inklusi tidak harus terlebih dahulu menekankan pada materi pembelajaran, tetapi yang paling penting adalah bagaimana memberikan perhatian penuh pada kebutuhan anak didik.

Jika ingin memberikan materi pelajaran kepada anak berkebutuhan khusus, harus memperhatikan kurikulum apa yang tepat dan sesuai dengan kebutuhan mereka. Kurikulum yang 


\section{PENDIDIKAN INKLUSI SEBAGAI ALTERNATIF SOLUSI...}

fleksibel harus menjadi prioritas utama dalam memberikan kemudahan kepada mereka yang belum mendapatkan layanan pendidikan terbaik demi menunjang karir dan masa depan. Berikan pula materi yang sesuai dengan kebutuhan mereka, terutama berkaitan dengan masalah ketrampilan dan potensi pribadi mereka yang belum berkembang.

b. Pendekatan Pembelajaran yang Fleksibel

Dalam aktivitas belajar mengajar, sistem pendidikan inklusi harus memberikan pendekatan yang tidak menyulitkan mereka untuk memahami materi pelajaran sesuai dengan tingkat kemampuan.

c. Sistem Evaluasi yang Fleksibel

Dalam melakukan penilaian harus memperhatikan keseimbangan antara kebutuhan anak berkebutuhan khusus dengan anak normal pada umumnya, karena anak berkebutuhan khusus memiliki tingkat kemampuan yang lebih rendah dibandingkan dengan anak normal pada umumnya sehingga memerlukan keseriusan dari seorang guru dalam melakukan penilaian.

d. Pembelajaran yang Ramah

Proses pembelajaran dalam konsep pendidikan inklusi harus mencerminkan pembelajaran yang ramah. Pembelajaran yang ramah bisa membuat anak termotivasi dan terdorong untuk terus mengembangkan potensi dan skill mereka sesuai dengan tingkat kemampuan yang dimiliki.

Karakteristik dalam pendidikan inklusi tergabung dalam beberapa hal seperti hubungan, kemampuan, pengaturan tempat duduk, materi belajar, sumber dan evaluasi yang dijelaskan sebagai berikut:

a. Hubungan Ramah dan hangat, contoh untuk anak tuna rungu: guru selalu berada di dekatnya dengan wajah terarah pada anak dan tersenyum. Pendamping kelas( orang tua ) memuji anak tuna rungu dan membantu lainnya.

b. Kemampuan

Guru, peserta didik dengan latar belakang dan kemampuan yang berbeda serta orang tua sebagai pendamping.

c. Pengaturan tempat duduk

Pengaturan tempat duduk yang bervariasi seperti, duduk berkelompok di lantai membentuk lingkaran atau duduk di 
bangku bersama-sama sehingga mereka dapat melihat satu sama lain.

d. Materi belajar

Berbagai bahan yang bervariasi untuk semua mata pelajaran, contoh pembelajarn matematika disampaikan melalui kegiatan yang lebih menarik, menantang dan menyenangkan melalui bermain peran menggunakan poster dan wayang untuk pelajaran bahasa.

e. Sumber

Guru menyusun rencana harian dengan melibatkan anak, contoh meminta anak membawa media belajar yang murah dan mudah didapat ke dalam kelas untuk dimanfaatkan dalam pelajaran tertentu.

f. Evaluasi

Penilaian, observasi, portofolio yakni karya anak dalam kurun waktu tertentu dikumpulkan dan dinilai (Takdir, 2013: 42-47)

\section{Manfaat pendidikan inklusi pada anak penyandang Disabilitas}

Penyelenggaraan pendidikan inklusif di Indonesia sampai saat ini memang masih mengundang kontroversi . Namun praktek sekolah inklusif memiliki berbagai manfaat.Dalam pendidikan inklusi, layanan pendidikan disesuaikan dengan kebutuhan kebutuhan khusus anak secara individual dalam konteks pembersamaan secara klasikal. Dalam pendidikan ini tidak dilihat dari sudut ketidakmampuannya, kecacatannya, dan tidak pula dari segi penyebab kecacatannya, tetapi lebih pada kebutuhan kebutuhan khusus mereka. Kebutuhan mereka jelas berbeda dari satu dengan yang lain.

Ada beberapa alasan pentingnya pendidikan inklusi dikembangkan dalam layanan pendidikan bagi anak luar biasa. Alasan tersebut antara lain:

a. Semua anak, baik cacat maupun tidak mempunyai hak yang untuk belajar bersama-sama dengan anak yang lain.

b. Seyogyanya anak tidak diberi label atau dibeda-bedakan secara rigid, tetapi perlu dipandang bahwa mereka memiliki kesulitan dalam belajar. 
c. Tidak ada alasan yang mendasar untuk memisah-misahkan anak dalam pendidikan. Anak memilki kebersamaan yang saling diharapkan di antara mereka.Ia tidak pernah ada upaya untuk melindungi dirinya dengan yang lain.

d. Penelitian menunjukkan bahwa anak cenderung menunjukkan hasil yang baik secara akademik dan sosial bila mereka berada pada setting kebersamaan.

e. Tidak ada layanan pendidikan di SLB yang mampu mengambil bagian dalam menangani anak di sekolah pada umumnya.

f. Semua anak membutuhkan pendidikan yang dapat mengembangkan hubungan antar mereka dan mempersiapkan untuk hidp dalam masyarakatnya.

g. Hanya pendidikan inklusi yang potensial untuk menekan rasa takut dalam membangun kebertemanan, tanggung jawab, dan pemahaman diri (Purwanta, 2002).

Dengan memperhatikan beberapa alasan tersebut, jelas dalam pendidikan inklusi kebutuhan anak akan terpenuhi sesuai dengan tingkat kebutuhannya. Kebutuhan anak dapat berupa kebutuhan yang bersifat sementara, permanen, dan kultural.Kebutahan sementara merupakan kebutuhan yang terjadi pada saat tertentu yang dialam oleh seorang anak.Misalnya adanya sikap positif bagi siswa berkelainan yang berkembang dari komunikasi dan interaksi dari pertemanan dan kerja sebaya. Siswa belajar untuk sensitif, memahami, menghargai, dan menumbuhkan rasa nyaman dengan perbedaan individual. Selain itu, anak berkelainan belajar keterampilan sosial dan menjadi siap untuk tinggal di masyarakat karena mereka dimasukkan dalam sekolah umum. Dan dengan sekolah inklusi, anak terhindar dari dampak negatif dari sekolah segregasi, antara lain kecenderungan pendidikannya yang kurang berguna untuk kehidupan nyata, label "cacat" yang memberi stigma pada anak dari sekolah segregasi membuat anak merasa inferior, serta kecilnya kemungkinan untuk saling bekerjasama, dan menghargai perbedaan.

Pada saat anak mendapat musibah, misalnya di sekolah ia tampak sedih dan membutuhan perhatian khusus. Anak membutuhkan orang lain untuk mencurahkan perasaan sedihnya.Kebutuhan permanen anak penyandang Disabilitasberupa 
kebutuhan untuk hidup mandiri dan wajar selayaknya orang lain dalam keluarga, sekolah, dan masyarakat. Seseorang anak penyandang Disabilitasdikatakan hidup normal apabila ia hidup bersama keluarga , dan belajar bersama-sama dengan anak-anak lain yang sebaya. Apabila ia hidup di asrama, belajar di sekolah khusus terpisah dengan anak lain di sekolah reguler, maka kehidupan anak tersebut tidak wajar. Kebutuhan kultural berkaitan dengan penerimaan kelompok terhadap anak di mana anak berada.Seoang anak perlu memperoleh kemudahan untuk diterima sebagai anggota dalam lingkungan kelompoknya.

Seorang anak penyandang Disabilitasmengalami banyak hambatan dalam menyesuaikan diri terhadap lingkungannya.Hal ini disebabkan keberadaan dirinya yang mempunyai keterbatasan beradaptasi dengan anggota-anggota lain di lingkungannya.Di samping itu, masyarakat sendiri belum sepenuhnya memahami kebutuhan anak penyandang Disabilitassehingga mereka kadangkadang bersikap kurang menerima kehadiran anak penyandang Disabilitas.

Keterbatasan fasilitas dan tidak fleksibelnya sistem pendidikan yang ada sekarang dan suasana lingkungan di sekolah tidak menjamin rasa aman bagi anal luar biasa dalam berintegrasi dengan lingkungannya.Pemenuhan kebutuhan anak penyandang Disabilitasmemerluakan perubahan, perubahan baik dalam sistem pendidikan, metode, maupun lingkungan, sehingga anak dapat menyesusaikan diri.

Dalam pendidikan inklusi, pemenuhan kebutuhan anak penyandang Disabilitastidak dimulai dari penyesuaian-penyesuaian anak terhadap sistem pendidikan, metode, maupun lingkungannya, melainkan seharusnya yang terjadi sebaliknya.Dalam suasana kelas, bukan anak yang menyesuaikan kurikulum, tetap kurikulumlah yang harus disesuaikan dnegan kebutuhan anak. Mendukung alasan perlunya pendidikan inklusi, beberapa argument para pendukung pendidikan inklusi adalah sebagai berikut ;

a. Belum ada banyak bukti empiris yang mendukung asusmsi bahwa layanan pendidikan khusus yang diberikan di luar kelas biasa menunjukkan hasil yang lebih positif bagi anak. 


\section{PENDIDIKAN INKLUSI SEBAGAI ALTERNATIF SOLUSI...}

b. Biaya pendidikan luar biasa yang relatif lebih mahal dari pada pendidikan umum.

c. Pendidikan di luar kelas biasa mengharuskan penggunaan label luar biasa yang dapat berakibat negatif bagi anak.

d. Banyak anak penyandang Disabilitasyang tidak mampu memperoleh layanan pendidikan karena tidak tersedia di sekolah terdekat.

e. Anak penyandang Disabilitasharus dibiasakan tinggal dalam masyarakat bersama warga masyarakat lainnya (Sunardi, 1995: 16).

Manfaat sekolah inklusi bukan hanya dirasakan oleh si anak, namun berdampak pula bagi masyarakat. Dampak yang paling esensial adalah sekolah inklusi mengajarkan nilai sosial berupa kesetaraan. Berdasarkan pengalaman dari sekolah segregasi, anak berkelainan disorot sebagai ancaman bagi masyarakat, maka dari itu harus dipisahkan, dan dikontrol oleh sekolah, bukan dibantu.

Sekolah inklusi bukanlah sekedar sekolah yang menerapkan konsep penyetaraan terhadap semua manusia dalam memperoleh pendidikan, tapi juga membutuhkan settinggan ramah anak didalamnya. Setting ramah anak ini sangat membantu dan mendorong kemajuan perkembangan penerapan pendidikan inklusi di sekolah.

Dimana para anak penyandang Disabilitassangat membutuhkan dukungan dan motivasi yang mampu mendorong mereka untuk berinteraksi dengan lingkungannya, maka komponen utama yang paling mereka butuhkan di sekolahnya adalah sebuah keramahan, yang menerjamahkan pada mereka suatu penunjukkan kondisi penerimaan terhadap diri mereka.

Partisipasi masyarakat dan adanya kemandirian menetukan berjalannya kebijakan sekolah inklusi ini. Karena dalam sekolah inklusi ini dibutuhkan kerjasama antara masyarakat dengan pengajar di kelas untuk menciptakan dan menjaga komunitas kelas yang hangat, menerima keanekaragaman, dan menghargai perbedaan.Selain itu dalam sekolah inklusi, guru-guru diharuskan untuk mengajar secara interaktif. Hal ini nantinya dapat menciptakan komunikasi antar guru dan siswa, sehingga dapat timbul kedekatan. Dengan adanya kedekatan tersebut akan menghilangkan adanya 
isolasi profesi. Dalam sekolah inklusi, makna orang tua juga berperan dalam menentukan perencanaan baik dari segi perencanaan kurikulum di sekolah maupun bantuan belajar di rumah.

\section{KESIMPULAN}

Anak penyandang Disabilitas juga merupakan anggota masyarakat dan mempunyai hak untuk berada di dalam lingkungan masyarakatnya.Mereka seyogyanya mendapat dukungan yang mereka butuhkan melalui system pendidikan, kesehatan, penyedia lapangan kerja dan pelayanan sosial yang berlaku umum. Karena penyandang Disabilitas memiliki hak-hak yang sama, mereka pun harus mempunyai kewajiban yang sama pula. Sebagai bagian dari proses persamaan kesempatan, sarana dan prasarana seyogyanya disediakan untuk membantu para penyandang Disabilitas agar mereka dapat mengemban tanggung jawab secara penuh sebagai anggota masyarakat.

Pendidikan inklusi yang menekankan kepada persamaan hak dan dan akses pendidikan kepada setiap warga Negara. Pada tataran implementasi pendidikan inklusi masih dihadapkan kepadaberbgai problema, isu, dan permasalahan yang harus disikapi secara bijak sehingga implementasinya tidak menghambat upaya dan proses menuju pendidikan inklusif itu sendiri serta selaras dengan filosofi dan konsep-konsep yang mendasarinya. Untuk itu diperlukan komitmen tinggi dan kerja keras melalui kolaborasi berbagai pihak, baik pemerintah maupun masyarakat untuk mengatasinya.Dengan demikian, tujuan akhir dari semua upaya di atas yaitu kesejahteraan para penyandang cacat dalam memperoleh segala haknya sebagai warga negara dapat direalisasikan secara cepat dan maksimal. 


\section{DAFTAR PUSTAKA}

Alimin, Z. (2005). Memahami Pendidikan Inklusif dan Anak Berkebutuhan Khusus.Makalah tidak diterbitkan. Bandung: Jurusan PLB FIP UPI.

Bandi Delphie. (2009), Pembelajaran Anak Berkebutuhan Khusus, Sleman: PT Intan Sejati

Departemen Sosial. (2009), Pedoman Advokasi Sosial Penyandang Cacat. Direktorat Pelayanan dan Rehabilitasi Sosial Penyandang Cacat.

Direktorat Pendidikan Luar Biasa. (2004), Mengenal Pendidikan Terpadu Ditjend. Pend. Dasar dan Menengah Dep. Pend.Nasional.

Fientje Palijama, Rehabilitasi Sosial Anak Cacat (Penerapan Prinsip Pengasuhan Anak Cacat Oleh Panti Sosial Bina Asih Leleani Di Kota Surakarta), Tesis. Program Pascasarjana, Ilmu Kesejahteraan Sosial, Bidang Ilmu Sosial Universitas Indonesia.

Mohammad Takdir Ilahi. (2013), Pendidikan Inklusif .Jogjakarta: ArRuzz MediaPurwanta (2002), Makalah disampaikan dalam Temu Ilmiah PLB Tingkat Nasional

Peraturan Mentri Pendidikan Nasional Nomor 70 Tahun 2009 Tentang Pendidikan Inklusif Bagi Peserta Didik yang Memiliki Kelainan dan Memiliki Potensi Kecerdasan dan/atau Bakat Istimewa

Sunardi (1995), Kecenderungan dalam Pendidikan Luar Biasa, Jakarta : Dikti, Dekdikbud.

Tarmansyah. (2007), Inklusi Pendidikan Untuk Semua, Jakarta: Depdiknas. 